Nevada

Environmental

Management

Operations Activity

\title{
Addendum to the
}

Closure Report for

Corrective Action Unit 357:

Mud Pits and Waste Dump,

Nevada Test Site, Nevada

Controlled Copy No.:

Revision No.: 0

October 2013

UNCLASSIFIED

/s/ Joseph P. Johnston

Joseph P. Johnston, N-I CO

$10 / 22 / 2013$

Date

Approved for public release; further dissemination unlimited.

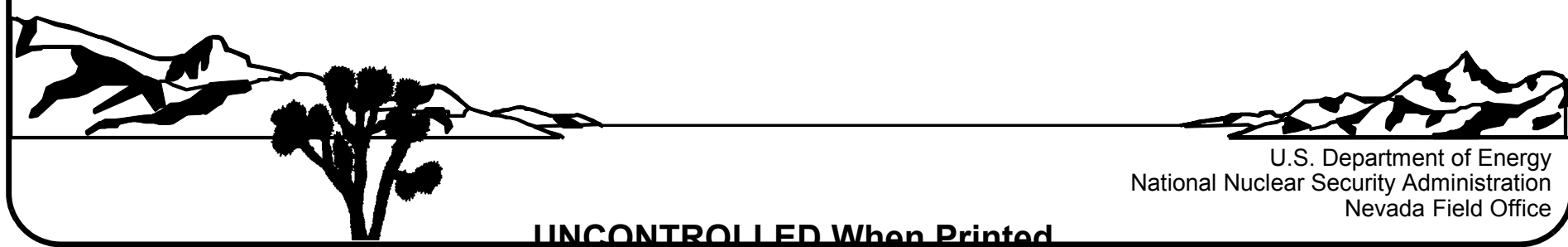


Available for sale to the public from:

U.S. Department of Commerce

National Technical Information Service

5301 Shawnee Road

Alexandria, VA 22312

Telephone: 800.553 .6847

Fax: 703.605.6900

E-mail: orders@ntis.gov

Online Ordering: http://www.ntis.gov/help/ordermethods.aspx

Available electronically at http://www.osti.gov/bridge

Available for a processing fee to U.S. Department of Energy and its contractors, in paper, from:

U.S. Department of Energy

Office of Scientific and Technical Information

P.O. Box 62

Oak Ridge, TN 37831-0062

Phone: 865.576 .8401

Fax: 865.576.5728

Email: reports@adonis.osti.gov

Reference herein to any specific commercial product, process, or service by trade name, trademark, manufacturer, or otherwise, does not necessarily constitute or imply its endorsement, recommendation, or favoring by the United States Government or any agency thereof or its contractors or subcontractors. 


\section{ADDENDUM TO THE CLOSURE REPORT FOR CORRECTIVE ACTION UNIT 357: MUD PITS AND WASTE DUMP, NEVADA TEST SITE, NEVADA}

U.S. Department of Energy, National Nuclear Security Administration

Nevada Field Office

Las Vegas, Nevada

Controlled Copy No.:

Revision No.: 0

October 2013

Approved for public release; further dissemination unlimited. 


\section{ADDENDUM TO THE CLOSURE REPORT FOR \\ CORRECTIVE ACTION UNIT 357: \\ MUD PITS AND WASTE DUMP, \\ NEVADA TEST SITE, NEVADA}

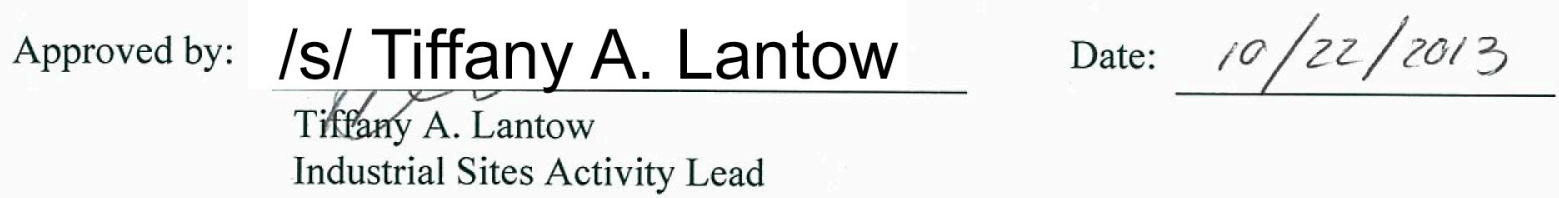

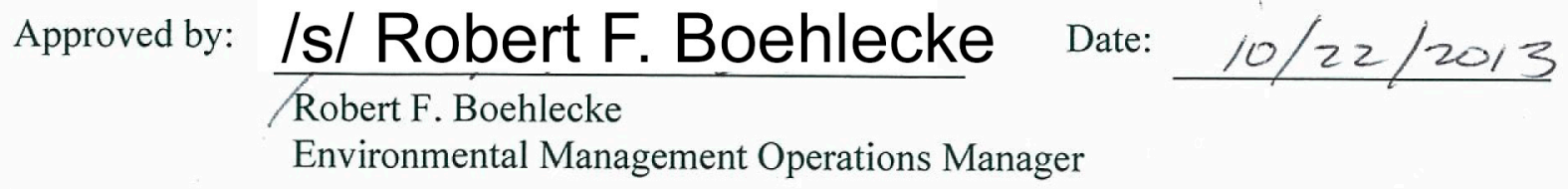




\section{Addendum to the Closure Report for Removal of the Use Restriction}

This document constitutes an addendum to the Closure Report for Corrective Action Unit 357: Mud Pits and Waste Dump, Nevada Test Site, Nevada (NNSA/NSO, 2005) as described in the document Recommendations and Justifications To Remove Use Restrictions Established under the U.S. Department of Energy, National Nuclear Security Administration Nevada Field Office Federal Facility Agreement and Consent Order (FFACO) dated September 2013. The Use Restriction (UR) Removal document was approved by the Nevada Division of Environmental Protection (NDEP) on October 16, 2013. The approval of the UR Removal document constituted approval of each of the recommended UR removals. In conformance with the UR Removal document, this addendum consists of:

- This page that refers the reader to the UR Removal document for additional information

- The cover, title, and signature pages of the UR Removal document

- The NDEP approval letter

- The corresponding section of the UR Removal document

This addendum provides the documentation justifying the cancellation of the UR for CAS 04-26-03, Lead Bricks. This UR was established as part of FFACO (FFACO, 1996; as amended) corrective actions and was based on the presence of lead contamination at concentrations greater than the action level established at the time of the initial investigation.

Although the lead concentration at the site is above the risk-based FAL, the re-evaluation resulted in a recommendation to remove this UR. The UR at CAS 04-26-03 is encompassed by the UR at CAU 370, CAS 04-23-01, Atmospheric Test Site T-4. Therefore, the lead contamination present at this site is monitored annually through the UR requirements for CAU 370, CAS 04-23-01. Requirements for inspecting and maintaining the CAS 04-26-03, Lead Bricks UR will be canceled, and the signage associated with the UR will be removed. This modification will not affect or modify any non-FFACO requirements for fencing, posting, or monitoring at this site. 


\section{References}

FFACO, see Federal Facility Agreement and Consent Order.

Federal Facility Agreement and Consent Order. 1996 (as amended March 2010). Agreed to by the State of Nevada; U.S. Department of Energy, Environmental Management; U.S. Department of Defense; and U.S. Department of Energy, Legacy Management. Appendix VI, which contains the Industrial Sites Strategy, was last modified May 2011, Revision No. 4.

NNSA/NFO, see U.S. Department of Energy, National Nuclear Security Administration Nevada Field Office.

NNSA/NSO, see U.S. Department of Energy, National Nuclear Security Administration Nevada Site Office.

U.S. Department of Energy, National Nuclear Security Administration Nevada Field Office. 2013. Recommendations and Justifications To Remove Use Restrictions Established under the U.S. Department of Energy, National Nuclear Security Administration Nevada Field Office Federal Facility Agreement and Consent Order, Rev. 0, DOE/NV--1510. Las Vegas, NV.

U.S. Department of Energy, National Nuclear Security Administration Nevada Site Office. 2005. Closure Report for Corrective Action Unit 357: Mud Pits and Waste Dump, Nevada Test Site, Nevada, Rev. 0, DOE/NV--1045. Las Vegas, NV.

U.S. Department of Energy, National Nuclear Security Administration Nevada Site Office. 2009. Corrective Action Decision Document/Closure Report for Corrective Action Unit 370: T-4 Atmospheric Test Site, Nevada Test Site, Nevada, Rev. 0, DOE/NV--1320. Las Vegas, NV. 
Nevada

Environmental

Management

Operations Activity

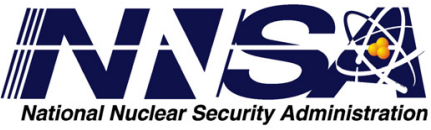

Recommendations and Justifications

To Remove Use Restrictions Established

under the U.S. Department of Energy,

National Nuclear Security Administration

Nevada Field Office

Federal Facility Agreement

and Consent Order

Controlled Copy No.: _

Revision No.: 0

September 2013

UNCLASSIFIED

Is/ Joseph P. Johnston, N-I CO 09/09/2013

Approved for public release; further dissemination unlimited.
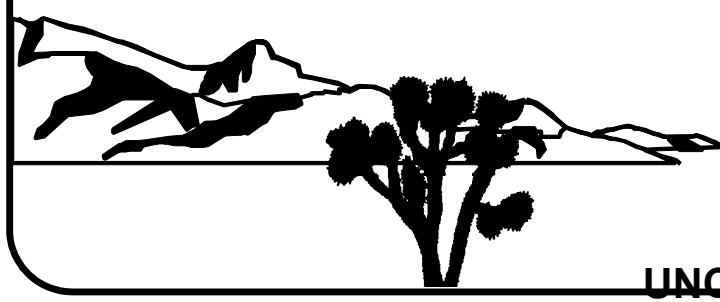
Available for sale to the public from:

U.S. Department of Commerce

National Technical Information Service

5301 Shawnee Road

Alexandria, VA 22312

Telephone: 800.553 .6847

Fax: 703.605.6900

E-mail: orders@ntis.gov

Online Ordering: http://www.ntis.gov/help/ordermethods.aspx

Available electronically at http://www.osti.gov/bridge

Available for a processing fee to U.S. Department of Energy and its contractors, in paper, from:

U.S. Department of Energy

Office of Scientific and Technical Information

P.O. Box 62

Oak Ridge, TN 37831-0062

Phone: 865.576 .8401

Fax: 865.576.5728

Email: reports@adonis.osti.gov

Reference herein to any specific commercial product, process, or service by trade name, trademark, manufacturer, or otherwise, does not necessarily constitute or imply its endorsement, recommendation, or favoring by the United States Government or any agency thereof or its contractors or subcontractors. 


\title{
RECOMMENDATIONS AND JUSTIFICATIONS TO REMOVE USE RESTRICTIONS ESTABLISHED UNDER THE U.S. DEPARTMENT OF ENERGY, NATIONAL NUCLEAR SECURITY ADMINISTRATION NEVADA FIELD OFFICE FEDERAL FACILITY AGREEMENT AND CONSENT ORDER
}

\author{
U.S. Department of Energy, National Nuclear Security Administration \\ Nevada Field Office \\ Las Vegas, Nevada
}

Controlled Copy No.:

Revision No.: 0

September 2013

Approved for public release; further dissemination unlimited. 


\subsection{CAU 357, CAS 04-26-03 - Lead Bricks}

\subsection{CAS Description}

CAS 04-26-03, Lead Bricks, is located in Area 4, north of 4-04 Road and west of the Big Explosives Experimental Facility (BEEF). The area of investigation is approximately 3.4 acres and consists of scattered lead bricks throughout an area west of the T-4 Bunker. The lead bricks at CAS 04-26-03 are believed to have been left in situ from activities associated with the Apple-1, Fox, Kepler, and Nancy tests, which occurred between 1952 through 1957. Radionuclide contamination is present at this CAS, but the scope of this CAS is chemical only, and the radionuclide contamination is addressed in CAU 370. During closure activities at this CAS, approximately 1,000 lead bricks or pieces of lead bricks ("high-density area") and associated soil were removed and contained, and a UR was implemented (NNSA/NSO, 2005b).

\subsection{Current UR Description}

The future use of any land related to this CAU is restricted from any DOE or USAF activity that may alter or modify the containment control, as approved by the State of Nevada and identified in the CAU CR or other CAU documentation, unless appropriate concurrence is obtained in advance. The UR is for surface and shallow subsurface contamination. Four monuments surround the CAS, and three UR signs are posted on the northeast, northwest, and southwest side of the CAS; a berm runs along the southeast side and is not posted. Inspections are conducted annually to ensure the monuments and UR signs are in good condition (NNSA/NSO, 2005b).

\subsection{Basis for Current UR}

To assist with the identification of buried or partially buried lead bricks and steel debris, geophysical surveys were conducted throughout the investigation. The survey data were used to identify areas having high magnetic conductance; these areas were excavated using shovels, and the lead/steel debris was removed. A metal detector was also used during the investigation to assist in distinguishing lead from steel debris. A "high-density area" was identified as having more than 400 lead bricks located very close to one another. Approximately 1,000 bricks or pieces of bricks 
were removed, and the lead-contaminated soil was excavated from beneath the removed bricks or clusters of bricks.

Surface and shallow subsurface samples were analyzed for lead only. After the bricks were removed, a minimum of two shovel scoops of soil was removed from beneath the former brick locations. A total of 91 Decision I shallow subsurface samples were then collected from the former brick locations. Concentrations of lead were above the PAL of $750 \mathrm{mg} / \mathrm{kg}$ in soil samples collected at 15 sample locations; the concentrations of lead ranged from 950 to $19,000 \mathrm{mg} / \mathrm{kg}$ (NNSA/NSO, 2005b).

Table 4-1 contains the Decision I sample analytical results for lead at CAS 04-26-03 that are the basis for the current UR. The sample matrix for all samples is soil.

Table 4-1

Sample Results for Lead at CAS 04-26-03 Used To Establish Current UR (Page 1 of 2)

\begin{tabular}{|c|c|c|c|}
\hline \multirow{2}{*}{ Sample Location } & \multirow{2}{*}{$\begin{array}{c}\text { Sample ID } \\
\text { (Decision I } \\
\text { samples) }\end{array}$} & \multirow{2}{*}{$\begin{array}{l}\text { Depth } \\
\text { (in. bgs) }\end{array}$} & Lead \\
\hline & & & $\begin{array}{c}\text { PAL } \\
750 \mathrm{mg} / \mathrm{kg}\end{array}$ \\
\hline \multirow{4}{*}{ M03 } & $357 \mathrm{M} 004$ & $0.0-4.0$ & 17,000 \\
\hline & $357 \mathrm{M} 010$ & $6.0-8.0$ & 3,500 \\
\hline & 357M064 & $12.0-14.0$ & 2,700 \\
\hline & 357M067 & $14.0-16.0$ & 1,100 \\
\hline M04 & 357M005 & $0.0-4.0$ & 1,700 \\
\hline \multirow{2}{*}{ M05 } & 357M006 & $0.0-4.0$ & 5,300 \\
\hline & $357 \mathrm{M} 063$ & $12.0-14.0$ & 1,200 \\
\hline \multirow{2}{*}{ M06 } & $357 \mathrm{M} 007$ & $0.0-4.0$ & 4,500 \\
\hline & $357 \mathrm{M} 018$ & $6.0-8.0$ & 1,300 \\
\hline M11 & $357 \mathrm{M} 011$ & $6.0-8.0$ & 950 \\
\hline \multirow{2}{*}{ M12 } & 357M012 & $4.0-6.0$ & 12,000 \\
\hline & $357 \mathrm{M} 013$ & $6.0-8.0$ & 5,000 \\
\hline M13 & $357 \mathrm{M} 014$ & $4.0-6.0$ & 3,700 \\
\hline
\end{tabular}


Table 4-1

\section{Sample Results for Lead at CAS 04-26-03 Used To Establish Current UR} (Page 2 of 2)

\begin{tabular}{|c|c|c|c|}
\hline \multirow[b]{2}{*}{ Sample Location } & \multirow{2}{*}{$\begin{array}{c}\text { Sample ID } \\
\text { (Decision I } \\
\text { samples) }\end{array}$} & \multirow{2}{*}{$\begin{array}{l}\text { Depth } \\
\text { (in. bgs) }\end{array}$} & Lead \\
\hline & & & $\begin{array}{c}\text { PAL } \\
750 \mathrm{mg} / \mathrm{kg}\end{array}$ \\
\hline \multirow{3}{*}{ M15 } & $357 \mathrm{M} 019$ & $0.0-4.0$ & 9,700 \\
\hline & 357M108 & $6.0-8.0$ & $760(\mathrm{~J})$ \\
\hline & $357 \mathrm{M} 110$ & $14.0-16.0$ & $4,300(\mathrm{~J})$ \\
\hline \multirow{2}{*}{ M16 } & 357M020 & $0.0-4.0$ & 14,000 \\
\hline & 357M066 & $12.0-14.0$ & 2,400 \\
\hline M17 & 357M021 & $0.0-4.0$ & 3,200 \\
\hline M74 & 357M091 & $6.0-8.0$ & 4,400 \\
\hline M76 & 357M093 & $6.0-8.0$ & 3,000 \\
\hline M85 & $357 \mathrm{M} 116$ & $0.0-4.0$ & $19,000(\mathrm{~J})$ \\
\hline \multirow{2}{*}{ M86 } & $357 \mathrm{M} 118$ & $0.0-4.0$ & $9,700(\mathrm{~J})$ \\
\hline & $357 \mathrm{M} 119$ & $6.0-8.0$ & $3,100(\mathrm{~J})$ \\
\hline M87 & $357 \mathrm{M} 120$ & $0.0-4.0$ & $4,700(J)$ \\
\hline
\end{tabular}

$\mathrm{J}=$ Estimated value.

Thirty Decision II samples were then collected at locations having lead above the PAL. These soil samples were collected to verify the vertical extent of lead in soil. The Decision II soil samples were collected at depths ranging from 6 to 8 in. bgs to 22 to 24 in. bgs across the site. The soil at these locations was excavated using shovels and contained on site for later disposal. A conservative estimate of the concentrations of lead in soil within the high-density area is $14,600 \mathrm{mg} / \mathrm{kg}$. (NNSA/NSO, 2005b).

\subsection{Basis for UR Modification}

Although lead is still a hazard in the form of potential buried lead bricks at CAS 04-26-03, CAU 370, T-4 Atmospheric Test Site, has an FFACO UR in place for lead in the form of potential source material (e.g., lead shielding within the T-4 bunker) and for radiological dose. The UR at CAU 370 encompasses the CAU 357, CAS 04-26-03 FFACO UR. Therefore, the lead contamination at CAS 04-26-03 will be addressed by the CAU 370 UR monitoring requirements, which include annual 
inspections of the UR signs and maintenance as needed (NNSA/NSO, 2009a). These modifications will not affect or modify any non-FFACO requirements at the site.

\subsection{Proposed Modification}

Although the estimated lead concentration at the high-density area is above the lead FAL for either IA or RW exposure scenarios, this FFACO UR may be removed. The associated monuments and postings may be removed, and the required annual inspections may be discontinued. The requirement for annual inspections of the UR postings at CAU 370, CAS 04-23-01 UR will remain, thereby ensuring that this area will be monitored annually. 
NNSA/NSO, see U.S. Department of Energy, National Nuclear Security Administration Nevada Site Office.

U.S. Department of Energy, National Nuclear Security Administration Nevada Site Office. $2005 b$. Closure Report for Corrective Action Unit 357: Mud Pits and Waste Dump, Nevada Test Site, Nevada, Rev. 0, DOE/NV--1045. Las Vegas, NV.

U.S. Department of Energy, National Nuclear Security Administration Nevada Site Office. 2009a. Corrective Action Decision Document/Closure Report for Corrective Action Unit 370: T-4 Atmospheric Test Site, Nevada Test Site, Nevada, Rev. 0, DOE/NV--1320. Las Vegas, NV. 


\title{
Library Distribution List
}

\author{
$\underline{\text { Copies }}$ \\ U.S. Department of Energy \\ 1 (Uncontrolled, electronic copy) \\ Office of Scientific and Technical Information \\ P.O. Box 62 \\ Oak Ridge, TN 37831-0062 \\ Southern Nevada Public Reading Facility \\ 2 (Uncontrolled, electronic copies) \\ c/o Nuclear Testing Archive \\ P.O. Box 98521, M/S 400 \\ Las Vegas, NV 89193-8521 \\ Manager, Northern Nevada FFACO \\ 1 (Uncontrolled, electronic copy) \\ Public Reading Facility \\ c/o Nevada State Library \& Archives \\ 100 N. Stewart Street \\ Carson City, NV 89701-4285
}

